\title{
混合性喉頭麻痺に対する段階的手術治療の経験
}

\author{
田山二 朗*, 村上 泰*, 水野 正 浩* \\ 野村 恭也*, 近藤 玲子**, 川端五十鈴** \\ 新美 成二***, 廣瀬肇***
}

\section{A Case of Severe Dysphagia and Dysphonia Improved by "Multi-Surgical" Treatments}

\author{
Niro Tayama, M.D.," Yasushi Murakami, M.D.," Masahiro Mizuno, M.D., \\ Yasuya Nomura, M.D., ${ }^{*}$ Reiko Kondo, M.D., ${ }^{* *}$ Isuzu Kawabata, M.D., ${ }^{* *}$ \\ Seiji Niimi, M.D., ${ }^{* * *}$ and Hajime Hirose, M.D. ${ }^{* * *}$ \\ *Department of Otolaryngology, and ***Research Institute of Logopedics \\ and Phoniatrics, University of Tokyo, Tokyo, and **Department \\ of Otolaryngology, Medical Center of Saitama University, Saitama
}

This paper concerns with a case with severe dysphagia and dysphonia caused by removal of a carotid body tumor. The patient, a 33-year-old female, was operated on for the removal of the right carotid body tumor. Since the operation, she had been suffering from severe misdiglutition associated with nasal leakage of liquid and severe dysphonia. Six months after operation, she was referred to our clinic. Clinical examinations revealed that her right IXth, $\mathrm{Xth}$, XIth and XIIth cranial nerves were paralyzed so that hemiatrophy and deviation of tongue, incomplete closure of the velopharyngeal port, poor constriction of the pharynx and right vocal cord fixation at the intermediate position could be the contributing factors for her complaints. In order to get complete closure of the glottis and to reduce the resistance of the esophageal entrance, medio-fixation of the right vocal cord (arytenoid rotation) with the cricopharyngeal myotomy was performed. Then, to get a tight sealing of the velopharyngeal port during swallowing, a pharyngeal flap operation was done. A small amount of silicone gel was injected to her paralysed vocal cord to improve her voice quality. After these "multisurgical" treatments, her swallowing and phonation ability improved satisfactorily.

Key words : dysphagia, dysphonia, multisurgical treatments

\section{I .はじめに}

嶼下障害は，われわれ耳鼻咽喉科医が多く経

*東京大学医学部附属病院耳鼻咽喉科学教室, $* *$ 埼玉 大学医療センター耳鼻咽喉科学教室, ${ }^{* * *}$ 東京大学医 学部音声言語医学研究施設

別刷請求：干113 東京都文京区本郷7-3-1 東京大学医学部耳鼻咽喉科 田山二朗

投稿受付：1990年 4 月24日
験する病態である。しかし，一言で䜩下障害と いっても原因は様々であり，その障害部位によ って治療法に苦慮することも多い。さらに喉頭 の持つ機能の複雑さ, つまり喉頭が嚥下のみな らず，呼吸・発声に関与する器官であることも， 䜩下障害の治療を困難なものにしている。今回 われわれは, 頸部腫場摘出術後の脳神経障害に よる,かなり重度の嚥下障害および発声障害が, 数回にわたる手術により著明に改善した症例を 
日気食会報，42（1）, 1991

経験したのでここに報告する。

\section{II . 症例}

症 例：33歳, 女性

主 訴：䁵下困難, 発声および構音障害

現病歷：高校時代より右頸部腫瘤に気づいて いたが放置していた。その後, 腫瘤が徐々に増 大してきたため某病院脳神経外科を受診したと ころ, carotid body tumor と診断され，1988年 9 月20日, 同脳外科にて腫瘍摘出手術をうけた。 腫瘍は頸静脈孔から第 6 頸椎椎体までにわたつ て存在し，神経線維と連続，さらに内頸動脈を 巻き込んでいた。このため，これを完全に摘出 するために止むを得ず第IX〜XII脳神経および 内頸動脈は切断された。術後より高度の嚥下障 害と発声障害が出現し, 気管切開下に嬩下訓練 を行ったものの改善がおもわしくなく，半年後 の1989年 3 月 3 日当科を紹介受診した。

来院時所見 : 体格栄養不良。舌は患側の萎縮 と突出時患側への偏位が認められた。右軟口蓋 の挙上は不良であり，鼻咽腔閉鎖不全が存在し た。発声時に咽頭後壁が左方へ移動するいわゆ るカーテン徵候も認められ, 右側咽頭収縮筋の 麻舫が示唆された。右声帯は萎縮し, 中間位で 固定していた。梨状陥凹には高度の唾液の貯留 が認められた。以上より IX〜XII 脳神経の麻痺 と考えられた。その他の身体の麻痺は認めなか つた。患者はカフ付きカニューレを装着し, 気 管孔より呼吸していた。食事は頸部を患側に捻 転し，外鼻を閉鎖して嚥下するという嚥下訓練 によりかろうじて摂食できるという状態であっ た。

検査所見：発声持続時間は数秒。ガストログ ラフィンによる食道透視検査（写真 1) では, 造影剂の上咽頭への逆流・梨状陌凹への貯留・ 食道への送り込みの障害・誤嬹が認められた。

嶼下時の咽頭内圧検査所見（図 1) では，外 鼻開放時での嚥下では下咽頭部の圧力は20 $\mathrm{mmHg}$ であったが, 外鼻を閉鎖して嶼下動作を 行うと $40 \mathrm{mmHg}$ に上昇した。

治療経過：これらの検査をふまえ，症状改善 のために段階的に手術を行った。

4 月 7 日。まず発声および嚥下時の声門の完 全な閉鎖と, 食道入口部括約筋の抵抗を弱める

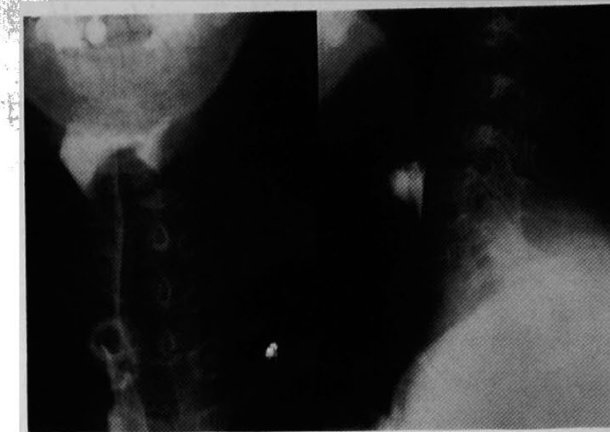

写真 1 食道造影

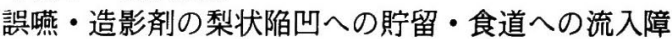
害を認める。
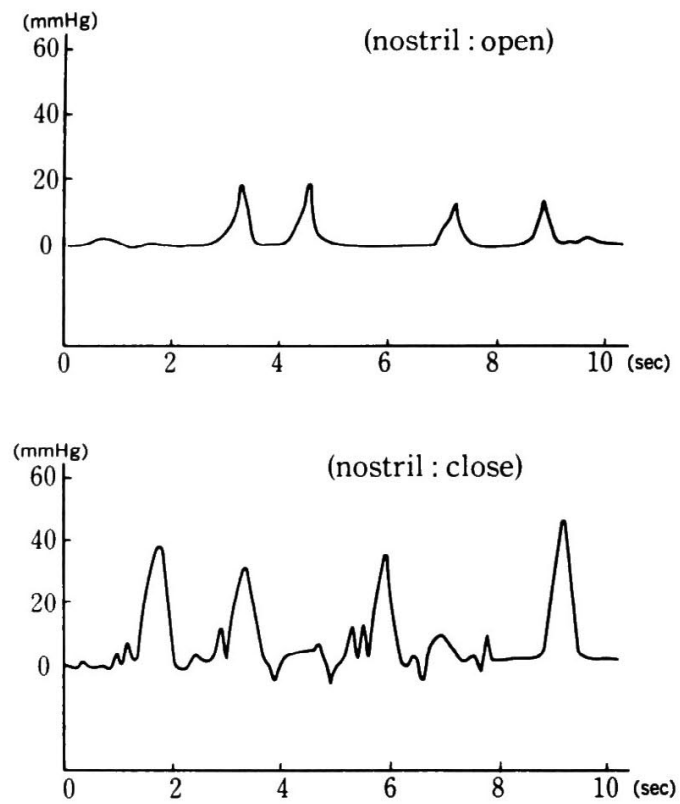

図 1 嚥下時下咽頭圧

外鼻開放では, 下咽頭圧は軽度上昇のみであるが, 外鼻閉鎖では嚥下圧の上昇が認められる。

ために，患側の披裂軟骨内転術と輪状咽頭筋切 断術を施行した。これにより発声持続時間の延 長と食道への流入障害に改善が認められた。し かし, 声帯の萎縮による嗄声が残ったことと, 嶼下に関しては，残存する鼻咽腔閉鎖不全によ り嚥下圧が十分確保できず，また上咽頭への逆 流分が睘下動作終了時に下咽頭に流れ落ち気道 に流れ込むために誤嚥が引き続き，嬩下機能は 完全には改善できなかった。 
5 月19日。鼻咽腔閉鎖不全および嗄声の改善 を目的に，咽頭弁形成術および声帯へのシリコ ン注入を行った。これにより嗄声も著明に改善 し, 嬹下障害もほほ消失した。

術後の喉頭所見を示す (写真 2 )。声帯はほほ 正中に位置し, 萎縮も改善され, 声門閉鎖不全 は消失した。梨状楩凹への大量の唾液の貯留も 減少し, 嬩下機能の良好なことが示唆される。

術後の食道透視所見を示す (写真 3 )。誤嬹・ 唾液の貯留は認められず, 造影剤の食道への流 入状態も良好になった。四燕下時の咽頭内圧検査 (図 2 )では, 術前に比し外鼻を開放したままで の咽頭内圧が上昇し, 鼻咽腔閉鎖不全の解消を 示した。

つまり，第一段階での披裂軟骨内転術と輪状 咽頭切断術, 第二段階での咽頭弁形成術および

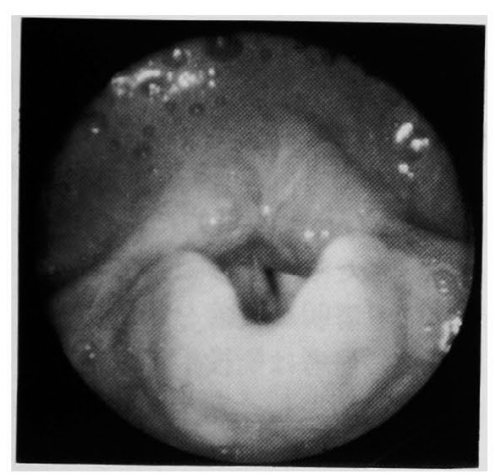

写真 2 術後喉頭所見 (発声時)

声帯の正中位での固定と梨状楩凹への唾液貯留の低 下が認められる。

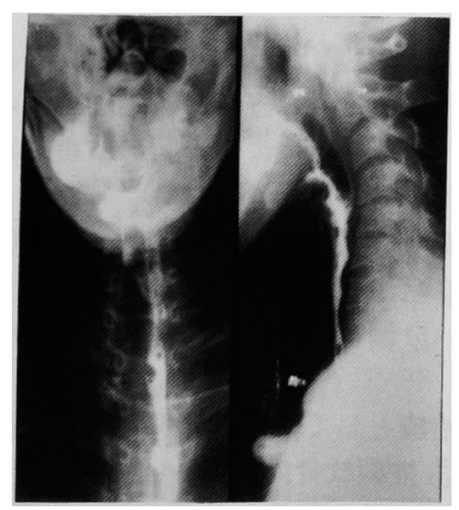

写真 3 術後食道造影所見

誤嚥の消失・梨状楩凹への唾液貯留の消失・食道へ の良好な流れ込みが認められる。

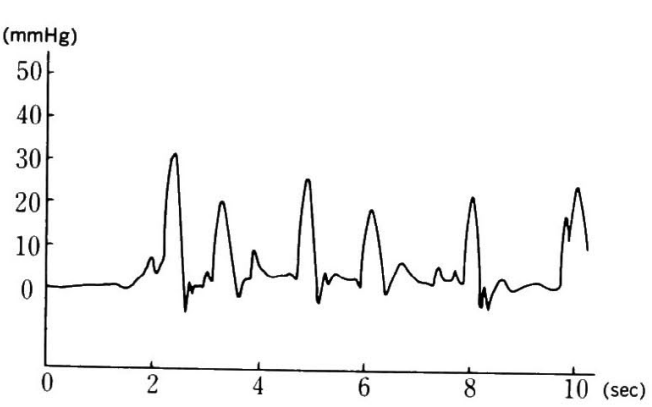

図 2 術後蔓下時下咽頭圧

外鼻を開放したままで下咽頭圧の上昇を認める。

声帯へのシリコン注入など, 段階的に種々の術 式を組み合わせて高度の嚥下障害と発声障害が 改善できた。

\section{III. 考 察}

喉頭は複雑な機能を有する器官である。つま り嶼下・呼吸・発声の三つの機能に関与してい る。「嶼下障害の治療」を考える際, これら多種 の機能の改善も合わせて解決せ标ばならないこ とが多く, 治療をむずかしいものにしている。

さて,この患者の障害状態を整理してみると,

1 ）嚥下障害に関して1

燕下は 3 相に分かれるが,

イ）第 1 相の送り込みに関しては，舌の萎縮は あるものの口腔から咽頭までの送り込みに は障害は認められなかった。しかし，下咽 頭までの送り込みに関しては, (1) 軟口蓋麻 舫による鼻咽腔閉鎖不全と, (2) 咽頭収縮不 全のために障害されていた。通常片側の軟 口蓋麻瘏のみでは嚥下障害は起こりにくい が3), この患者の場合, 咽頭側壁の収縮が不 良であることが加わり障害が起こったと考 えられる。

口）第 2 相は下咽頭から食道入口部への移行で ある。この時期には咽頭内圧の上昇・下咽 頭収縮筋群の弛緩と収縮(特に輪状咽頭筋) および声門の閉鎖が起こるが, 軟口蓋麻痺 による鼻咽腔閉鎖不全・咽頭収縮不全・輪 状咽頭筋の運動障害・声帯の中間位での固 定によりこれら三者が障害されていた。

八）第 3 相に関して, つまり食道通過に関して は問題はなかった。 
以上より，この患者の場合嚥下の第 1 相およ び第 2 相，特に第 2 相が障害されていたと考え られた。

2 ) 呼吸との関連，つまり誤嚥に関して 声門閉鎖不全が存在するため, 嚥下時, 喉頭 上昇期に気道への流れ込みが観察されると同時 に，喉頭下降期にも上咽頭への逆流した分およ び梨状楩山の貯留したものが気道に流れ込み， 誤嚥を引き起こすと考えられた。

3 ) 発声障害に関して

声帯の中間位固定による声門閉鎖不全と声帯 の萎縮が原因であり，これに鼻咽腔閉鎖不全に よる軽度の開鼻声が加わっていた。

以上の問題点を改善するための手術として, 以下の手術が考えられた。

1）鼻咽腔閉鎖不全：咽頭弁形成術

2 ）咽頭収縮不全：咽頭縫縮術

3 ) 声門閉鎖不全：披裂軟骨内転術

4 ）声帯萎縮：シリコン注入術

5 ) 輪状咽頭筋弛緩障害：輪状咽頭筋切断術 具体的には，第一段階の手術として，披裂軟 骨内転術・輪状咽頭筋切断術を施行し，声門閉 鎖不全・輪状咽頭筋弛緩障害の改善を試みた。 第二段階の手術として, 咽頭弁形成術・咽頭縫 縮術・シリコン注入術を施行し，鼻咽腔閉鎖不 全・咽頭収縮不全・声帯萎縮の改善を試みた。

手術を二段階で施行したのは，患者の肉体的 および精神的負担の軽減と，手術手技上の問題 である。第一段階の披裂軟骨内転術では，声門 閉鎖不全を改善し，誤輏の軽減と有響性発声を 可能とした。音質に関しては声帯の萎縮が強く 結局シリコン注入を必要とした。このシリコン 注入の時期は，披裂軟骨内転術による声带の炎 症が治まった後に，その効果，つまり声帯の術 後の位置と萎縮の程度を正確に把握し，必要を 認めれば二次的に施行するのが望ましいと判断 した。また通常片側の軟口蓋麻痺のみでは嚥下 障害は起こりにくいとされており4)，この症例 でも, 輪状咽頭筋切断術を施行し, 輪状咽頭筋 弛緩障害を改善することのみで，曣下機能の改 善がある程度期待された。しかし，前述したご とく側壁の収縮が悪いことも加わって, 鼻咽腔 閉鎖不全は予想よりかなり高度であった。この ため輪状咽頭筋切断術後も，喉頭下降期に上咽
（障 害）
（原 因）
（治 療）

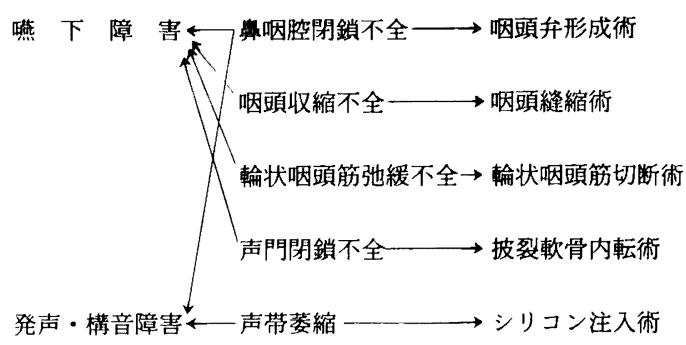

図３＼cjkstart障害・原因・治療の関係のまとめ

頭への逆流した分，および梨状陥凹の貯留した ものが下気道に流れ込む誤嚥が残り,これを改 善する手術が必要となった。

以上から，第二段階の手術としては咽頭弁形 成術・咽頭縫縮術・シリコン注入術を施行し, 鼻咽腔閉鎖不全 - 咽頭収縮不全 - 声带萎縮を改 善させた。

この症例のごとく, 複数の脳神経障害に起因 する咽喉頭の機能障害は, その機能障害の部位 と程度を詳細に検討し, 種々の機能外科的術 式 ${ }^{5 \sim 9)}$ を組み合わせ，段階的に治療することが 要求される。またそうすることにより，かなり 高度な障害でも著明な改善を期待することがで きる。なおこの患者は術後半年以上経た現在, 障害はほとんど消失し，完全な社会復帰を果た している。

最後に患者の障害・その原因・治療の関係を まとめたものを図 3 に示しておく。

\section{IV. 結 語}

1 ) 頸部腫瘍摘出後の脳神経障害による重篤 な嚥下障害と発声障害が, 段階的種々の手術を 組み合わせることにより著明に改善した症例を 報告した。

2 ) 嶼下障害の原因としては, (1) 鼻咽腔閉鎖 不全, (2) 咽頭収縮不全, (3) 声門閉鎖不全, (4)声 带萎縮, (5) 輪状咽頭筋弛緩障害などが考えられ た。

3) 治療として, (1) 咽頭弁形成術, (2) 咽頭縫 縮術, (3) 披裂軟骨内転術, (4) シリコン注入術, (5) 輪状咽頭筋切断術を施行した。

本論文の要旨は第 6 回世界気管食道科学会議（東 
京）にて発表した。

\section{文献}

1) 沢木修二, 設楽哲也, 野村恭也：臨床耳鼻咽喉 科学 1-基礎編, pp.404-412, 中外医学社, 東京, 1976.

2 ) 進 武幹, 前山忠嗣, 森川郁郎 - 他: 嶼下のメ カニズムとその障害. 耳鼻臨床, $77: 2475-2486$, 1984.

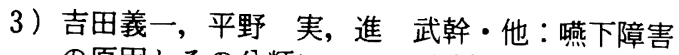
の原因とその分類について. 耳喉, 48:699-702, 1976.

4 ) 平野 実: 嶼下障害の手術的治療. 耳鼻, 22 : 696-702, 1976.
5 ）佐藤文彦：反回神経麻瘏に対する音声外科的治 療。音声外科における最近の進歩, pp.161-185, 医学教育出版, 東京, 1984.

6 ) 岩村 忍, 竹内貴志子：反回神経麻痺に対する シリコン注入治療。日気食会報, 35：17-27, 1984.

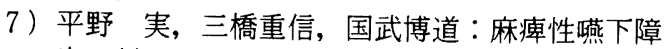
害に対する手術的療法一輪状咽頭筋切断術およ び咽頭弁形成術一。日耳鼻, 76:1067-1072, 1973.

8 ) 平野実: 嚥下障害における輪状咽頭筋切断 術. 耳喉, $46: 807-810,1974$.

9 ）平野 実：音声外科の基礎と臨床，耳鼻，21： 239-442, 1975. 